\title{
Manipulative Rhetoric in 17th and 18th Century Sermons: Aporia, the Borders of Reason
}

\author{
Cristina Garrigós \\ University of León \\ c.garrigos@unileon.es
}

\begin{abstract}
It is my aim in this paper to explore the role of aporia as a rhetorical instrument that is used in religious sermons in order to manipulate the audience and try to convince them of a truth derived from the textual evidence of the Bible. In this context, aporia appears as a rhetorical figure by which the speaker expresses to be in doubt about a question, or presents an insoluble paradox or contradiction in the text's meaning. I believe that the function of aporia in religious sermons has never been analysed as yet. To that extent, I will illustrate my thesis with three examples by John Donne, Jonathan Edwards and Laurence Sterne, three preachers who, faced with an insurmountable border - the necessity of explaining rationally the ineffable - recur to aporia in their discourses. It is my contention that the three sermons that I will discuss here exemplify what Derrida called the "plural logic of aporia" and show different ways in which the ministers can manipulate their audience to make them reach a certain truth, by convincing them of the impossibility to have access to that truth by themselves, therefore relying on the final authority of the Bible.
\end{abstract}

When a man prophesies, he is talking to men, and his words have the power to build; they stimulate and encourage.

I Corinthians 14:3 


\section{Introduction}

Do sermons always pretend to tell the truth? Essentially, they do, since they try to persuade the audience of the veracity of something. However, many times, in order to convince the addressees of a truth, the rhetorical strategy employed to that effect implies the negation or questioning of the very assertion that is to be proved. This rhetorical device is called aporia. The word aporia, from the Greek $\alpha \pi o \rho i \alpha$ 'without a passage, path or way', appears for the first time in Aristotle's Metaphysics. Etymologically, aporia refers to that which cannot be trespassed and is related to the ways to have access to truth and has been discussed by philosophers such as Heidegger, Kant, Hegel or Derrida. Derrida understands aporia as both the impossibility (final frontier) and the path to that impossibility (or the lack of it). According to him (Derrida, 1998: 42-44), aporia is plural: it can be understood as the border that cannot be trespassed; as something that has a boundless nature, since its limits are too permeable, porous and indeterminate; and as the impracticable, the antinomy or contradiction, where there is no possible path. Derrida discusses the plural logic of aporia related to death. However, in this paper, although I will rely on his definition of aporia, I will apply it to religious discourse instead. Thus, it is my aim to explore the role of aporia as a rhetorical instrument that is used in religious sermons in order to manipulate the audience so as to convince them of a truth derived from the textual evidence of the Bible by means of the negation or questioning of the message, by creating doubt in the listeners, or by acknowledging the impossibility of trespassing the borders of reason and of explaining the inexpressible through language. In my opinion, religious discourse is mostly aporetic since, faced with a border which cannot be trespassed (the access to God, or the truth), it relies on the idea of Faith, the final paradox, for its significance.

As we will see, many sermons are aporetic in structure, using doubt and negation as rhetorical instruments in order to ascertain a point. Albeit apparently contradictory in its essence, this device allows the speaker to eliminate any doubt in the mind of the hearers by establishing the contradiction in the text as an insolvable condition, relying thus in Faith as the only possible way to truth. I believe that this is a new approach in rhetorical criticism insofar as the function of aporia in religious sermons has never been analysed as yet. To that extent, I will illustrate my thesis with three examples by John Donne, Jonathan Edwards and Laurence Sterne, three authors and preachers who, faced with this insurmountable border the necessity of explaining rationally the ineffable - recur to aporia in their discourses. It is my contention that the sermons of these three authors exemplify what Derrida termed the "plural logic of aporia" and show different ways in which the ministers can manipulate the audience to make them reach a certain truth. Moreover, I believe that the three of them exemplify different ways that sermons can be manipulative: John Donne, the converted Anglican, full of doubts and contradictions; Jonathan Edwards, representing the Puritan discourse of fear and punishment, and Laurence Sterne, the satiric humanist. From England to the New World, and back again, in a transatlantic critical enterprise, this essay sets out to explore the diverse, and often startling, strategies that were used in sermons to contribute to the ideological construction of the Church. 


\section{Sermons and rhetorical manipulation}

In the $17^{\text {th }}$ century, the pulpit was a place for the dissemination of ideas, a place to exert political and religious power. Sermons were not only heard at church, but often copied and read in homes, where they were subject of reflection and meditation. Both from the pulpit and from the press, the discourse of the sermons was popular and high-minded at the same time. They were by far the most pervasive medium for influencing public opinion at this time (Shami, 1992: 1). Readers constantly called for reprints of old sermons and were eager recipients of the new ones. As such, compared to the number of plays, poems, translations and other literary texts published in the $17^{\text {th }}$ century, sermons and religious works in general, including theological tracts, comprise by far the majority of works printed. ${ }^{1}$ As Smith (1978: 5) points out, the same phenomenon is reported all over Europe at this period: "large congregations sitting (or standing) spellbound at the feet of a preacher who, by the power of his eloquence and personal magnetism, was able to hold their attention for an hour or possibly longer". This was something common to both Catholics and Protestants in Spain, France, England and New England, and its importance was such, that it has left an indelible trace, not only in the minds of their contemporaries, but also in their writings, as well as in the literary traditions that come up to our own days. Sermons cannot be considered as isolated pieces, but as part on an ongoing and organic whole. In this sense, Medhurst (1989:289) states: "From the city-states of ancient Greece, to the Medieval churchmen, to the English Puritans arriving on the shores of New England, civil-religious rhetoric has flowed and ebbed, but never disappeared". However, the Catholic sermon has little importance if compared to the relevance it has in the reformed service. For Protestants, preaching is the most important part of the worship. If the Catholic Church teaches its message through images (pictures, crosses, virgins), the Protestant one, with its nude walls and the iconoclast abolition of any representation has to make use of the words as symbols. Hence the importance of the oratorical discourse, and specially that of the pulpit, since it has a double purpose: to instruct and to persuade (Mc Comb, 1926: 57).

The fragmentation of the text into separate pieces was an inheritance of the Scholastic tradition, which was no longer fashionable in the $17^{\text {th }}$ century, although its influence was still felt in the Puritan sermons, fond of minute and exhaustive division and subdivision of their subjecty. This is specially clear in the sermons of the New England Puritans, invaluable examples of the colonial enterprise undertaken by the Europeans at the time. And in this sense, sermons should be understood not as specific instances of religious writing, but as literary pieces that combine the poetical and the rhetorical in a unique way. Moreover, the sermon was a genre of undeniable importance in the shaping of the American mind, as has been pointed out by several authors (Miller, 1953; Bercovitch, 1974; Elliot, 1975). The sermon represents a bridge uniting both the Old and the New World. As such, the close relationship between the development of the sermon and the establishment of the first cities in New England can be considered parallel to the settlement of rhetoric in the Greek world as art and technique of the persuasive discourse that was intimately related to the development of the polis and democracy as an institution. In fact, rhetoric, in the sense of the expression of the word, should be in essence opposed to the authoritarian use of power. However, it can turn into a dangerous 
weapon when used for manipulative purposes. ${ }^{2}$

To some extent, sermons have been examined by scholars from diverse perspectives: from a sociological perspective (what the sermon says, who says it and to whom), from a historical perspective (when and where), and from a rhetorical one (how it says it). T.S Eliot (1932:323), for instance, compared the sermons of John Donne and Lancelot Andrewes and emphasized the literary quality of the texts. In the case of some sermons, poetics and rhetoric, two disciplines often differentiated from Aristotle on, meet. ${ }^{3}$ This is specially evident in those texts written by such ministers of the church as John Donne, Edward Taylor or Laurence Sterne, whose pieces combine rhetorical art with poetic imagery. To illustrate such combination, Burke (1966:296) pointed out to Fénelon's saying that "Good oratory is almost poetry," implying the difficulty of distinguishing these two disciplines, and to Longinus's quoting both from Homer (a poet) and Demosthenes (an orator), in order to provide examples for his theory of the sublime. Thus, some sermons can be considered truly poetic in their images, albeit being persuasive or dissuasive in the idea. However, the didactic function needs to be performed in a convincing and appealing way, so that we can relate its rhetorical strategies to Longinus's concept of the sublime - the power to conceive and express great ideas and to move the reader, which, according to him, was attained by means of the five sources of lofty style (the most productive one). ${ }^{5}$

Like Longinus's speaker, the preacher has to choose carefully his words and images in order to make his argumentation effective and convince or persuade his pew. Thus, most expository sermons begin with a selected scriptural passage (psalm, incident, parable, or verses). Then, the preacher treats the various facts with the detail needed to explain them, so as to impress upon the congregation the central message of the text. The spiritual essence of a sermon lies in the element of revelation, that is, the perception of spiritual truth. This is something common to all sermons: the absolute belief that there is an ultimate truth to be revealed. The preacher has to be, or at least appear to be, convinced of the certainty of such truth and of the veracity of his message to be able in turn to convince his audience.

Moreover, the best way to convince of a truth is through the control of the emotions and reasoning of the audience. In order to move, the words of the sermon must form a picture in the audience's mind, a quality which Horace attributed to good poetry ("ut pictura poiesis"). This image has to stir the emotions through the imaginative power of the mind, but the emotional quality of sermons should be based on reason, as Coleridge says: "Every attempt in a sermon to cause emotion, except as the consequence of an impression made on the reason and understanding of the will, I hold to be fanatical and sectarian". 6 The emotions prepare the mind to accept the idea defended in the sermon but it is the logical argument what opens up a way towards truth.

It should be clear then, that rhetorical manipulation is something common to all sermons, whatever their theological ascription, whatever the time or place of their performance. No doubt, rhetorical art is essential to effective argumentation and oratory, but the path to the truth, as Derrida said, is often difficult, sometimes impossible, to find. As said above, the orator often makes use of aporia, a rhetorical tool that consists in questioning the very claim he is trying to make and to show the inner contradiction of a text. In order to do that, he positions himself, so to speak, as the devil's advocate. The aporia becomes thus the final 
paradox, the dismantling of the very structure of the text so as to affirm its sense. This is a very common manipulative tool in preaching. But what happens when aporia is used in order to perplex the mind and to stir the emotions? The presentation of an apparently insoluble paradox may thus determine the communication between the speaker and the hearer, and the success of the sermon, which, as we have seen, depends on the combination of thought and feeling. And this is precisely one of the most important characteristics of John Donne's poetry and his sermons, as I will analyse in the following section.

\section{Contradiction in speech: John Donne' sermons}

Well known for his inclusion among the metaphysical poets, John Donne was born into a Roman Catholic family and yet was ordained Anglican minister in 1615. From this year up to his death in 1631, Donne was a very active preacher, although only one hundred and sixty of his sermons have survived in print. In his own words, he turned "from the mistress of my youth, Poesy, to the wife of mine age, Divinity" (Fuller, 1964: xii). With this ironical comment, Donne tried to establish a clear-cut division between rhetoric and poetry, but further exploration of his sermons will prove not only that this separation is not true, but that both his poetry and his preaching are interconnected in such way that enables us to speak of a continuum in his work. For Donne, sermons are not only meant to be persuasive (rhetorical) but also poetical as well as ethical. In his own words:

He that brings that (any collateral respect) to a sermon loses the blessing of God's ordinance in that sermon; he hears but the logic, or the rhetoric, or the ethic, or the poetry of the sermon, but the sermon of the sermon he hears not (Sermon on St. Luke 2:29, 30).

Although Donne rejected Catholicism (very likely due to political reason) still, his writing has a dramatic and dark tone that critics have compared to Baroque aesthetics and that is uncommon to other Anglican contemporaries, such as Lancelot Andrewes, John Bowle or Hugh Latimer. According to Warnke (1987: 91), the defining features of Donne's sermons are essentially the same as those of his poetry: dramatic immediacy, personal intensity, compelling rhythms, and an extravagant use of conceited images. Donne's sermons are fundamentally dialogical, based on the cooperation between the audience and the preacher and between this and God. As he himself acknowledges: “...man is that creature, who onely of all other creatures can answer the inspiration of God, when his grace comes, and exhibit acceptable service to him, and cooperate with him"(I. S7. 126-129). In his opinion, the preacher is above men in the pulpit, but as a man, he is also among them in prayer. Thus, according to Carrithers (1972:20), "The preacher is by turns servant, master, and brother-inChrist to all Sons of God". The sermon is a communal, inclusive, dramatic exercise, a performance where the preacher is the only one who speaks, but he is continually addressing the audience and requiring of them to take an active part in the function. To this effect, in his sermons he uses, among other devices, compelling rhythms and lexical repetition that pursue an emotional and dramatic effect. This, united to the recurrent themes in his sermons (the ineffable mercy of God, the Communion of the Saints, human brotherhood, the power of 
prayer and, above all, the longing for the union with God) made of his preaching an entertaining albeit didactic activity. However, his theological position is all but clear. For most critics (Warnke, 1987: 92), he did not stress the controversial points of Christian doctrine, emphasising rather the items of faith on which Puritan, Anglican, Protestant and Catholic agree. And yet, as Shami (2000: 6) insightfully points out, "readers seldom try to make sense out of Donne's apparently contradictory statements, too often preferring to quote selectively to support their general sense of Donne's religious position and political alignment". And this is precisely one of the purposes of this paper, to present Donne's use of aporia as a characteristic of his contradictory speeches.

Donne sees himself as the connecting factor between the congregation and God, but being human, he also partakes of a weak and sinful nature. His ultimate desire is for him and for his audience to reach the final union with God. But there are several problems to be solved in order to reach that perfect state. The most evident is how a sinful human being can be united with God. A good example of this paradox is his sermon "Of Human Marriage and the Marriage of Soul with Christ; a Wedding Sermon". Written in 1621 and preached at the marriage of Margaret Washington, the sermon tackles a very sensitive question for Donne: the issue of marriage as union and the (im)possibility of divorce. This sermon is an excellent example of rhetorical criticism. Donne begins with the sentence "The word which is the hinge upon which all this text turns is erash and Erash signifies not only a betrothing, as our later translation hath it, but a mariage" (p. 1) (sic). Through the use of close reading, the author unfolds the text before the ears of the congregation dismantling it completely, so that the audience might get a full meaning of its implication specially by putting into question the main thesis of the text: the indissolubility of marriage. As such, the author/preacher offers us an exercise of erudite biblical exegesis by deconstructing and analysing the biblical text in order to prove human weaknesses and frailties, which are only overcome by the power of the Divine word. The rhetorical structure of this sermon is a classical one: presentation of the text; proposition; elaboration; application. The rationale of his text is to analyse marriage as the perfect union by establishing a parallelism between human and divine marriage. From the root of the biblical quote, "And I will marry thee unto me forever" (Hosua 2.19) the text follows the scholastic method, ramifying in divisions and subdivisions to cover any single point that could cast any doubt upon the listeners. Donne takes the biblical text and, word by word, analyses the biblical meaning of marriage, focusing on the last word Forever and discussing the relation of the institution of marriage to eternity. In order to do that, Donne explains the three different types of marriage that correspond to the three different types of love (physical, spiritual and divine) and so, he distinguishes between:

1. secular marriage in paradise (Adam and Eve).

2. spiritual marriage in the Church (Christ and humankind).

3. eternal marriage in Heaven (humankind and God).

For Donne, marriage is not only a civil contract made in front of other people, that is, a public activity (condemning thus other types of union, such as clandestine marriages or illicit unions $^{7}$ but a spiritual one, since it has to be given by a priest, the representative of God. To 
that extent, Donne explains to his pew the purposes of marriage (from less to more important): remedy against burning; propagation; mutual help. After the subdivision of the text that establishes the different bonds that are created by marriage, Donne lays before the consideration of his hearers the possibility of the marriage being broken, only to immediately negate such prospect: "Those whom God has joined no man, no Devil can separate". Then he introduces the problem of adultery as a potential motif for the dissolution of the marriage. Hence the aporia of the text: although Donne sees the sinful humanity implicit in the union of the lovers, and he is forced to acknowledge the possibility of adultery, he cannot accept sin and failure as motifs for divorce, since that would destroy his idea of the perfect union with God. Therefore, being unable to find a way out of this contradiction, Donne solves the problem of adultery by relying on the authority of St. Agustine, who remains silent on this subject, and considers it a "deadly wound":

I pronounce not now whether Adultery dissolves mariage or not; It is $S$. Agustines wisdom to say, Where the Scripture is silent, let me be silent too; And I may goe lower than he, and say, Where the Church is silent, let me be silent too; and our Church is so far silent in this, as that it has not said that Adultery dissolves marriage. Perhaps then it is not the death of mariage, but it is a deadly wound. (p. 9)

The aporia or the text (the preacher's inability to find a way out of this question) is present in the apparent repetition of the last sentence: "Perhaps then it is not the death of mariage, but it is a deadly wound": what is the difference between death and a deadly wound? If the wound is mortal, then this is synonymous of death, hence, although he does not specify it clearly, adultery implies the dissolution of marriage. Donne does not want to accept the possibility of divorce on the grounds of adultery, but at the same time, he has to accept the possibility of the existence of adultery within the marriage, due to the weak and sinful nature of human beings. Besides, since the recommendation a priori of not having an extramarital affair is not enough to solve the ethical dilemma, he decides to leave it there for the audience to elucidate. It is a question without an answer, an aporia, or a contradiction with the final message on the unity of marriage.

Contradiction and paradox is inherent in Donne's life and writing. ${ }^{8}$ For him, the eternal essence of secular marriages is undeniable but only "as far as this world admits any eternity" (p. 9). Moreover, he admits that eternal marriage cannot be defined because it is inexpressible, hence another aporia of the text: "And for the third marriage, the eternall marriage, it is a boldnesse to speak any thing of a thing so inexpressible as the joyes of heaven; it is a diminution of them to goe about to heighten them; it is a shadowing of them to goe about to lay any colours or lights upon them (p. 10). The very point he is trying to make - that of marriage as the final union (forever) - is difficult to demonstrate due to the acknowledgement of its potential weakness. The elaboration of the sermon develops this idea. The elaboration considers the nature of the participants in the marriage (Human marriage: man and woman; Spiritual marriage: Christ and humans) and considers the sinful nature of humans versus the perfect nature of Christ. Finally, in the Application he goes back to secular marriage to reinforce the idea that it is also a type of spiritual marriage, therefore a type of the eternal and he finishes with an antithesis: Christ's incorruptible blood. 
In this sermon, John Donne offers us then an exegetical and aporetical interpretation of the Biblical text, since the main point he is trying to prove, the indissolubility of marriage, is presented as a paradox. To such extent, Donne is accomplishing a close reading much related to modern literary criticism, specially to descendants of the rhetorical school, such as New Criticism and, more recently, deconstruction, displaying the fissures of the text, and hence, paradoxically, of marriage, in order to prove its compactness and the power of God's words.

\section{Puritan aporia: Jonathan Edwards's Angry God}

The manipulative power of the sermon becomes specially evident in the case of Puritan sermons. Although the Puritan sermon discussed important political and social issues of the day, the might of the sermon lied in its symbolic and metaphorical meaning, which resulted from a dynamic between the clergy and their people. In a very interesting study on the manipulative potential of sermons in Puritan New England, Elliot analysed the relationship between the first generation of Puritans (1630's-1650's) and the second generation (1670's1680's). According to Elliot (1975:41), the emphasis in the sermon during the first years was upon the New England Dispensation of salvation that Christ had won for men through his death. Then, there is a change from the assurance of salvation to exclusiveness and isolationism due mainly to economic and religious factors. The ministers sought to regain control of the people by stressing uncertainty. They transmitted the idea that election was unsure, and transformed the idea of the calling into an effective tool for creating doubt and, incidentally, lessening the spiritual value of one's practical life. As a result, there were many inner tensions (nervous breakdowns and suicides were not uncommon).

The power of the Church in Puritan New England was enormous. Besides the family, the Church became the most powerful institutional tool for controlling the young people of the second generation. Many of these ministers came from England. The sermons produced in New England, especially in the $17^{\text {th }}$ century, are undoubtedly the best revelation of the framing of the New England mind. The sermon was the central and commanding incident in their lives; theatres were forbidden and the religious service was the only possible communal gathering for both men and women. These were used to long religious services, which lasted from three to five hours, being the sermon the main part of about two hours. It was customary to bring the notebook to church and to take notes on the sermons. Of these English ministers, one of the most influential was Jonathan Edwards (1703-1758) whose sermons, specially his most famous one, "Sinners in the Hands of an Angry God" (1741), were certainly different from those by other preachers that, according to Elliot, conveyed "a message of assurance and hope". Kimnach (1989) points out that Edwards possessed an intense imagination, but his verbal skills were different from the Baroque aesthetics of John Donne or Edward Taylor. For Kimnach (1989: 115), Edwards preferred to bring his listeners as close as possible to their reality so as to achieve an immediate effect in the audience. To such extent, one of his favourite techniques was repetition: simple and incremental repetitions are employed to induce a maximum of contemplation with a minimum of verbal deflection from the subject of meditation. By restating, the preacher achieves both increased emphasis and the sense of 
continuity in time, dramatizing both the importance and the endurance of the subject handled. The form of the sermon dramatizes the preacher's act of mediation by its structure, placing doctrinal development between scriptural interpretation and practical exhortation. Influenced by Locke, Edwards was a kind of Christian scientist, a Christian philosopher, who was trying to pursue an ultimate reality through Christ.

In "The true Excellency of a Gospel Minister,"Edwards (1829:443) said that the ministers "are set in the church of God ... to be the instruments of leading souls to the God of all consolation ... they are sent as Christ was, and as co-workers with him, to preach good tidings to the meek, to bind up the broken hearted...". Thus, he did not conceive the task of the preacher to frighten his congregation, and when he did so, he did it in a way that he left a door open for hope. Such is the case of Edwards's best known sermon, "Sinners in the Hands of an angry God". The key to the sermon is in the word wrath, which is repeated over and over. Human beings are sinners and God is angry with us and ready to let us fall into a burning pit. The aporia of the text is thus introduced by creating doubt in the certainty that sustains us: the belief that we can trust God. The audience is suddenly faced with the following paradox: if God, that is supposed to support the creatures he had created, is wrathful and angry with us, what are the certainties or hopes that hold our beliefs? What is the role of the Devil, then? Paradoxically, God appears in this sermon as a threatening evil, incarnating vengeance and hate. This implies, of course, a redefinition of the traditional image of God and of His role towards us. As a good Calvinist, the God in the sermon is that of the Old Testament, and $\mathrm{He}$ is angry with sinful humans (the wicked Israelites in the Biblical text that opens the sermon: Deuteronomy 32:35, "And their foot shall slide in due time"). It depends on His power only to let sinners fall into a burning pit. However, there is a door for salvation to be found in Christ, who appears at the end of the application presenting the opportunity for escaping the awful fate: "And now you have an extraordinary opportunity, a day wherein Christ has thrown the door of mercy wide open and stands in, calling and crying with a loud voice to poor sinners, a day wherein many are flocking to Him and pressing into the kingdom of God: "Haste and escape for your lives, look not behind you, escape to the mountains, lest you be consumed" (Edwards, 2000: 102). We can be saved by Christ's mercy. Thus, by presenting God as angry, ready to kill human beings, he contrasts Him with Christ's humanity and redeeming compassion.

As regards to the structure, the sermon is quite traditional: Edwards gives four implications of the text and ten "observations" upon his reading of it, before he passes on to the application. The arguments cluster around Edwards's proposition: "There is nothing that keeps wicked men at any moment out of hell, but the mere pleasure of God" (p. 76). With this sermon, Edwards's purpose was to awaken unconverted persons in this congregation. He knew that Enfield was a difficult audience that was resisting the Great Awakening. Edwards's success, according to most critics, was due to his use of imagery, since it is the imagery what gives the discourse its emotional power. It is my contention, however, that Edwards's real success relies in the use of aporia as a manipulative rhetorical tool, since he establishes a contrast between God and Christ, that is, between punishment and salvation, that is not solved until the very end of the sermon.

There are about twenty five images in this sermon. Edwards used conventional images: 
"Israelites-bitter and poisonous fruit", "The sword of divine justice" "The old serpent". However, as Cady (1980: 260) points out, these images were so common that they could not awaken a congregation, as Edwards wanted to. Other images, such as, "the arrows of death fly unseen at noon-day; the sharpest sight cannot discern them" "Black clouds" were quite weak. According to Cady, he redesigned the old images by combining them with a new reality: danger of floods, "Walk in slippery places" was something common to every winter in New England, etc. Edwards makes the audience participate imaginatively in an act they knew physically. However, the climatic figure was undoubtedly the spider upon the pit of fire. It was probably at this point that Edwards was forced to request silence from a "breathing of distress and weeping", as Eleazar Wheelock reported (cited in Kidd, 2007: 104). These images awakened in the congregation an imaginary of Fires of hell and symbols of God's wrath (threatening sword, the storm, the flood, the bow, the wine-press, the grape-treading Deity) but "Sinners" is not directly concerned to create Hell imaginatively. The focus is on the uncertain fate of the sinner and on the idea of an imminent damnation. This reinforces the aporia of the text: the idea that religious faith relies precisely in this indeterminacy. Thus, I agree with Cady that his problem of expression was (like Donne's) to find a means to drive out into effective form his overpowering sense of inward reality. In my opinion, though, that problem was not solved only by the use of startling images, but by the use of aporia.

\section{Puzzling the audience: Laurence Sterne's sermons.}

If the Anglican sermons of the early $17^{\text {th }}$ century, such as Donne's, for instance, were highly ornate with a complex structure of divisions, as Fanning (1997: 416) notices, the Restoration and the $18^{\text {th }}$ century Anglican sermon is notable for its lack of such ornate structures, concentrating on methodical argument. Fanning considers that "Sterne's approach (to preaching) is that of the Sophists - the tradition of Cicero and Quintilian - which posits a relative, contingent truth, identifying eloquence as the source of social harmony" (1997:415). Other preachers, such as Swift, he considers more Platonic, favoring philosophy over rhetoric. Thus, albeit contemporary of Jonathan Edwards, Laurence Sterne in England represents a radically different attitude and conception not so much of preaching, but of the rhetoric of preaching, even though the influence of John Locke's theories can be traced in the writings of both preachers. Very different from Edwards's puritanism, however, the author of The Sermons of Mr. Yorick did not receive some positive critical attention until 1870, when Paul Stapfer published his book Laurence Sterne: sa personne et ses ouvrages. Victorian critics dismissed a minister that would write so irreverent texts, to the extent that Thackerey called him "vain, wicked, witty and false" and said that his sermons "had not a single Christian sentiment"; Leslie Stephen said he was "a literary prostitute" and Bagehot considered him a pagan (Downey, 1969: 115-118). Fortunately, $20^{\text {th }}$ century literary criticism since Stapfer and, specially since Lance Van der Heyden Hammond's Laurence Sterne's Sermons of Mr. Yorick (1948) has changed considerably the portrait of Sterne as a man, a minister and a writer. Reporting his preaching, Richard Greenwood told Joseph Hunter that: "When he preached the audience was quite delighted with him, \& he never preached at Sutton but half the 
(congregation) were in tears - the Minster was crowded whenever it was know that he was to preach - he used often to preach nearly extempore" (Downey, 1969: 150).

The sermons of Mr. Yorick originated in Sterne's Tristram Shandy. According to Downey (1969: 120), in this novel Sterne had partly anticipated, partly created, a market for his new sermons. He published the first two volumes of The Sermons of Mr. Yorick in 1760, assuring his readers that these were genuine sermons, and that "not one of them was composed with any thoughts of being printed" (Sterne, 1996: 1) It was not until 1765 that he decided to publish two more volumes of Yorick's sermons, and finally in 1769 - a year after Sterne's death - his wife and daughter, aware of the enormous financial success of the other sermons, managed to have eighteen more published in three volumes under the title Sermons by the late reverend Mr. Sterne.

In his sermons, Sterne speaks of trust and the tragedy of betrayal; he speaks of conscience, of love and of temptation, but above all, Sterne stresses the need for compassion in all human relationships (Downey, 1969: 128-129). There is almost a complete absence of doctrinal exposition in the sermons. He never questions the authority of the Church or the Bible, but stresses instead the communal and social aspects of religion. In this respect, he states: "The great end of all religion ... is to purify our hearts- and conquer our passions- and in a word, to make us wiser and better men, better neighbours - better citizens- and better servants to God" (Sterne, 1996: 80). His sermon "Vindication of Human nature" illustrates his philosophy perfectly: he believes that since God has created man and that we partake of his Divine nature, man must be essentially good. Therefore, it is "false" and "pernicious" to say that the whole world is wicked. Sterne was free of the Puritan condemnation of others and neurotic selfdoubts; he trusted man's moral capacity and place in a secure universe ruled by God's fair judgement. This is the "optimisme modéré" that Stapfer (2009: 126) pointed out in his writings. A preaching from the heart, as he has Yorick say in Tristram Shandy:

To preach, to shew the extent of our reading, or the subtleties of our wit - to parade in the eyes of the vulgar, with the beggarly accounts of a little learning, tinselled over with a few words which glitter, but convey little light and less warmth - is a dishonest use of the poor single half hour in a week which is put into our hands - 'Tis not preaching the gospel-but ourselves. For my own part, continued Yorick, I had rather direct five words point-black to the heart. (1987:314)

Just as Jonathan Edwards, Sterne had read Locke too. But unlike him, he believed that man was not so much depraved as deprived of good motives. As Downey (1969: 154-155) says, "for Sterne the pulpit is no longer the Mount Olympus it was for men like Donne and Taylor a century before. The preacher no longer stands six feet above contradiction; he is but a man speaking to men, cognizant of the limitations to both his person and his office". Unlike Edwards's repetition, Sterne recurred to the technique of digression in his sermons profusely, as he had done in his novel Tristam Shandy. Apart from digression, he is fond of figures such as personification, interrogation, aposiopesis, erotesis, apostrophe, antithesis, asyndeton, irony and humour. But what Sterne uses most is aporia, and in a very metarhetorical sense: he uses rhetoric to deny it, that is, to persuade his audience (through rhetoric) to lead a more virtuous life without having to recur to figures of speech. Sterne appears to disregard the conventions of sermon construction, as Thomas Gray, the pre-romantic poet, noticed in a 
letter:

Have you read his sermons (with his own comic figure at the head of them)? They are in style I think most proper for the pulpit \& shew a very strong imagination \&a sensible heart: but you see him often tottering on the verge of laughter \& ready to throw his perriwig in the face of his audience. (Downey, 1969: 147)

A good example of Sterne's preaching technique is the sermon "The House of Feasting and the House of Mourning Described". The technique he uses in this sermon is a quite unusual one: thesis, antithesis and synthesis. The sermon begins with the typical Biblical quotation, in this occasion the text chosen is Ecclesiastes VII, 2,3: "It is better to go to the house of mourning than to the house of feasting." But then, strangely enough, the preacher starts abruptly with a refutatio: "That I deny": Amazingly, the preacher denies the statement of the Biblical text. The audience, we can imagine, is shocked to see how the preacher seems to challenge the final authority of the Bible:

That I deny-but let us hear the wise man's reasoning upon it- for that is the end of all men, and the living will lay it to his heart: sorrow is better than laughter-for a crack'd-brain order of Carthusian monks, I grant, but not for men of the world: For what purpose, do you imagine has GOD made us? For the social sweets of the well watered vallies where he has planted us, or for the dry and dismal deserts of a Sierra Morena? are the sad accidents of life, and the uncheery hours which perpetually overtake us, are they not enough, but we must sally forth in quest of them, - belie our hearts, and say, as your text would have us, that they are better than those of joy? Did the Best of Beings send us into the world for this end - to go weeping through it, - to vex and shorten a life short and vexatious enough already? (p.12)

The aporia of the text is clear in the negation of the biblical quotation: if the main thesis of the sermon is the superiority of the house of mourning, why then start with an antithesis, the negation of such superiority? The manipulative purpose of the use of aporia in this example is evident: the author wants to defamiliarize the reader with the text to ultimately dismantle any inner doubt that arises in the mind of the audience that may understand that the message of the Bible is not very convincing in itself. In order to do that, since it is the function of the Minister to defend the Biblical text and not to question it, as Fanning (1997:428) points out, "there is a counter-rhetorick at work, for in the last analysis, Sterne contradicts his first reading of the text and returns to an orthodox position". Thus, he ends up condemning the house of feasting instead, to say that the pleasures in it are empty ones and that once the desire is fulfilled it leaves no improvement for the soul.

The final conclusion leads us back to the beginning so as to affirm the validity of the Scriptures. Hence, in the end, through the image of a widowed mother whose son has died, the congregation is persuaded to choose the house of mourning, not because sorrow is better than joy, but because the lessons it teaches are more valuable. Therefore, in this example, Sterne uses aporia (negation) as rhetorical manipulation to take the audience to the truth he wants them to reach: the main aim of the human being in this world is not to find pleasure in it, but to learn lessons of wisdom, which may allow them to reach the better world in the afterlife. 
Traugott (1954: 98) argues that Sterne, in the tradition of Erasmus, Rabelais and Swift, is a facetious rhetorician, indulging his ingenious fancy and manipulating dialectical devices to ensnare the reader and force him to examine his motives for behaviour. Sterne was aware of the power of rhetoric to delight or disturb an audience. Through the use of aporia, he was constantly exploiting his hearers' emotions: first by offending their moral sensibilities by a seemingly blasphemous statement, then, by means of some adroit dialectical footwork, eluding to blame himself while leaving his congregation to puzzle the reason for its outrage. Thus, Downey (1969: 137) remarks,

With Sterne the sermon comes closer to passing over entirely into the field of literature than with any other preacher of the $18^{\text {th }}$ century. He dispenses with practically all homiletic appurtenances; there is nothing to indicate an outline -no major headings, subdivisions, or Roman numerals, no repetition, recapitulations, and nothing which even faintly resembles a peroration. Only the presence of a Biblical text distinguishes one of Sterne's sermons from a vigorous moral essay.

One cannot but agree with Downey (1969: 154) when he says that Sterne's sermons are examples of a very specific attitude: in the 18th century, the traditional hierarchy of literary genres was finally overthrown; the epic poem was supersed by the novel and in homiletics, the spirit was manifested in an attempt to rid the form of the sermon of the rigidity of classical oratory. This change will be definitive in the 19th and 20th centuries, but even though the form of the sermons may be less rigid, the use of rhetorical tools for manipulative purposes will remain unshaken.

\section{An aporetic conclusion}

To conclude, in this paper we have seen three examples of the use of aporia for manipulative purposes in 17 th and 18 th century sermons: Donne's impossibility to define the eternal nature of marriage, Edwards's insistence on the wrathful nature of God, only to reinforce his mercy, and Sterne's negation of the Biblical text as a means to affirm its unquestionable essence. In my opinion, these three examples correspond to what Derrida (1998:42-44) sees as the plural logic of aporia: he understands aporia as the existence of a border that cannot be trespassed (Sterne); as having a boundless nature, since its limits are too permeable, porous and indeterminate (Edwards); and as the impracticable, the antinomy or contradiction, where there is no possible path (Donne). The three examples above show different ways in which the preachers can manipulate the audience to make them reach a certain truth. Moreover, the examples that we have considered touch upon three of the most conflictive points in Christianism which converge in one: the idea of sin. Donne had problems connecting the weak nature of human beings with the eternity promised by the Christian message; Edwards developed the topic of guilt and punishment as something imminent, creating anguish and fear over the destiny of the human soul by focusing on the absence of the Mercy of God; and Sterne tried to convince his audience of the benefits of a religion based on suffering and penance, instead of a more hedonistic one, which is something that another minister, George Herbert, had done before in his poem "The Collar". However, challenging as it is, the three of them 
achieve their objective: to convince of the validity of their message, not by reason, but by recurring to a rhetorical tool: aporia. A figure that, by startling and confusing the addressee, achieves what the preachers are looking for: the fact that faced with an insurmountable barrier the believers have to recur to faith in the Bible as the ultimate option.

The privileged position of the preacher, thanks to the absolute control of discourse in the liturgical context, grants him/her an objective superiority to his pew, although Anglican ministers, such as Donne and Sterne, have a less rigid position in this matter than a puritan like Edwards. For the latter, the central emphasis was on the Word: the Bible was the ultimate source of truth and the minister was God's messenger. In this respect, the function of the preacher was to persuade and convince the audience of a certain message in order to avoid dissent. Thus, we can see many examples of the use of such technique in the history of sermonic discourse, but specially in the $17^{\text {th }}$ and $18^{\text {th }}$ centuries. The persuasive discourse of sermons has always been linked to the ways to know the truth, but clearly, even though the speakers may be convinced of the validity of such truth, the path to get there is often full of traps.

\section{Notes}

1. Godfrey Davies has estimated that over 360,000 sermons were delivered in the first 40 years of the $17^{\text {th }}$ century (quoted by Jeanne Shami, 1992: 1).

2. That was the credo of the psychagogic rhetoric ('soul driver') in Greece, for instance. Such rhetoric did not want to convince people that a given argument was believable (eikos) by means of a demonstration technically spotless, but by means of the attraction that the words, wisely manipulated, could effect upon the audience. The result that they wanted to achieve was emotive reaction, not rational adhesion. Such an effect, that of the emotive reaction that would lead to a specific action (Cicero's movere or flectere), determined the attitude of the orator, the use of the language and the choice of a determined symbology.

3. Julius Caesar Scaliger in Poetices Libri Septem (1561) distinguished clearly rhetoric that was limited to prose, from poetics, destined to verse compositions.

4. Fénelon also said "There is no eloquence at all without poetry" in Three Dialogues On Pulpit Eloquence- Francois de Salignac de Lamothe Fénelon . London: Thomas Baker, 1897, p. 64.

5 . The five sources are the following: 1 . Faculty of grasping great conceptions; 2 . Passion, strong and impetuous; 3 . The proper handling of figures (of thought and of diction); 4. Noble phraseology, with its divisions and subdivisions (choice of words and use of tropes and elaboration); 5. Dignified and spirited composition.

6. Specimen of the Table Talk of Samuel Taylor Coleridge. Henry Nelson Coleridge, Ed. London and New York: George Routledge \& son, 1836, p. 176.

7. Interestingly enough, Donne himself had been married in secret, without the consent of Ann Donne's father, and had spent some time in prison for it.

8. Moreover, from a historical perspective, we have to take into account that Donne had supported the divorce of Frances Howard from Robert Deveraux, on the ground of his impotence, in order to marry Robert Carr, who was her lover. Donne had even written an epithalamion for their wedding in 1613 , since he was looking for the patronage of Carr, who was the favorite of King James I. When both Carr and Howard were declared guilty of the death of Thomas Ovenbury (who had opposed Frances's divorce and therefore their wedding) and sent to the Tower of London, Donne probably felt quite 
embarrassed for having supported, more or less implicitly, Frances Howard's extramarital affair.

\section{References}

Bercovitch, Sacvan (1974): The American Puritan Imagination. Cambridge: Cambridge University Press.

Burke, Kenneth (1966): Language as Symbolic Action. Berkeley: University of California Press.

Cady, Edwin H (1980): "The artistry of Jonathan Edwards". In W. J. Scheick, ed., Critical Essays on Jonathan Edwards. Boston: G. K. Hall, 257-264.

Carrithers, Gale H(1972): Donne at Sermons. A Christian Existential World. Albany: State University of New York Press.

Coleridge, Henry Nelson, Ed. (1836): Specimen of the Table Talk of Samuel Taylor Coleridge. London \& New York: George Routledge \& Son.

Davies, Godfrey (1939): “English political sermons, 1603-1640”. Huntington Library Quarterly 1: 1-22.

Derrida, Jacques (1998): Aporías. Barcelona: Paidós.

Donne, John. John Donne Sermons (Digital Collection at Brigham Young University). Available at: http://www.lib.byu.edu/dlib/donne/

Downey, James (1969): “A Theological Flap Upon the Heart”. The Eighteenth century Pulpit. A Study of the Sermons of Butler, Berkeley, Secker, Sterne, Whitefield and Wesley. Oxford: Clarendon Press, 115-154.

Edwards, Jonathan (1829): Works, VIII. Dwight, Sereno E., Ed. New York: Converse.

Edwards, Jonathan (2000): Pecadores en manos de un Dios airado. (bilingual edition). In J. A. Gurpegui, ed., Julio César Santoyo, trad. León: Taller de Estudios Norteamericanos, 57.

Eliot, T.S (1932): "Lancelot Andrewes". Essays in Ancient and Modern. New York: Harcourt, Brace \& Co., 3-23.

Elliot, Emory (1975): Power and the Pulpit in Puritan New England. Princeton: Princeton University Press.

Fanning, Christopher (1997): "Sermons on sermonizing: The pulpit rhetoric of Swift and Sterne". Philological Quarterly 76 (4): 413-436.

Ferrell, Lori Ann and McCullough, Peter (eds.) (2000): The English Sermon Revised. Religion, Literature and History 1600-1750. Manchester: Manchester University Press.

Fuller, Edmund (1964): The Showing Forth of Christ: John Donne's Sermons. New York: Harper \& Row.

Kidd, Thomas S. (2007): The Great Awakening: The Roots of Evangelical History in Colonial America. New Haven: Yale University Press.

Kimnach, Wilson H (1980): “The Brazen Trumpet: Jonathan's Edward Conception of the Sermon". In W. Scheick, ed., Critical Essays on Jonathan Edwards. Boston: G.K Hall, 277-286.

Kimnach, Wilson H (1989): “Jonathan Edwards's pursuit of reality”. In N. O. Hatch and H. S. Stout, eds., Jonathan Edwards and the American Experience. New York: Oxford University Press, 102-117.

McComb, Samuel (1926): Preaching in Theory and Practice. Oxford: Oxford University Press.

Medhurst, Martín J. (1989): "The politics of prayer: A case study in configurational interplay”. In T. W. Benson, ed., American Rhetoric: Context and Criticism. Carbondale: Southern Illinois University Press, 267-292.

Miller, Perry (1953, rep. 1966): The New England Mind: From Colony to Province. Boston: Beacon 
Press.

Scheick, William J. (ed.) (1980): Critical Essays on Jonathan Edwards. Boston: G.K Hall.

Shami, Jeanne (1992): "Introduction: Reading Donne's sermons". John Donne Journal vol. 1 \& 2: $1-19$.

Shami, Jeanne (2000): "Anti-catholicism in the sermons of John Donne" In L.A Ferrell and P. McCullough, eds., The English Sermon Revised. Religion, Literature and History 1600-1750. Manchester: Manchester University Press, 136-166.

Smith, Hillary Dansey (1978): Preaching in the Spanish Golden Age. Oxford: Oxford University Press.

Stapfer, Paul (1870, rep. 2009): Laurence Sterne: sa personne et ses ouvrages. Charleston, SC: BiblioLife.

Sterne, Laurence (1759-67, rep. 1987): The Life and Opinions of Tristam Shandy. Hardmonsworth: Penguin.

Sterne, Laurence (1996): The Sermons. The Florida Edition of the Works of Laurence Sterne. Vol. IV. Melvyn New, ed. Gainsville: University Press of Florida.

Traugott, John (1954): Tristam Shandy's World: Sterne's Philosophical Rhetoric. Berkeley: University of California Press.

Warnke. Frank J. (1987): John Donne. Boston: G.K Hall \& Co. 